\title{
HUKUM PERNIKAHAN STATUS MAHASISWA
}

\author{
Masyhadi \\ IAI Al Khoziny Buduran Sidoarjo \\ Email: masyhadi.mau@gmail.com
}

\begin{abstract}
Law Married to Students, While He Still Can Maintain Himself. Students who are still in college mean that they are undergoing an obligation, which is studying. While marrying his original law is still a sunnah for him, it is not mandatory, as long as he can still maintain the sanctity of his soul and morality, and not fall into the haram even though he is not married. Therefore, in such a situation the rules of aulawiyat (legal priority) must be established, namely that which is obligatory must take precedence over the sunnah. That is, lectures must be prioritized rather than married. If you still want to get married, then the law is still sunnah, not mandatory, but he is required to be able to carry out these two laws (studying and marrying) at the same time, not neglecting one, accompanied by having to fulfill the readiness of marriage property, and physical
\end{abstract}

Key word: Student, Meriried, Law

\begin{abstract}
ABSTRAK
Hukum menikah bagi Mahasiswa, sedang Dia masih dapat menjaga dirinya. Mahasiswa yang masih kuliah, berarti mereka sedang menjalani suatu kewajiban, yaitu menuntut ilmu. Sedangkan menikah hukum asalnya adalah tetap sunnah baginya, tidak wajib, selama dia masih dapat memelihara kesucian jiwa dan akhlaqnya, dan tidak sampai terperosok kepada yang haram meskipun tidak menikah. Karena itu, dalam keadaan demikian harus ditetapkan kaidah aulawiyat (prioritas hukum), yaitu yang wajib harus lebih didahulukan daripada yang sunnah. Artinya, kuliah harus lebih diprioritaskan daripada menikah. Jika tetap ingin menikah, maka hukumnya tetap sunnah, tidak wajib, namun dia dituntut untuk dapat menjalankan dua hukum tersebut (menuntut ilmu dan menikah) dalam waktu bersamaan secara baik, tidak mengabaikan salah satunya, disertai dengan keharusan memenuhi kesiapan menikah seperti yakni kesiapan ilmu, harta, dan fisik.
\end{abstract}

Kata Kunci: Mahasiswa, Menikah, Hukum

\section{PENDAHULUAN}

Pernikahan mahasiswa bukanlah suatu hal yang baru untuk dibicarakan, problem ini sangat sering diangkat dalam berbagai seminar dan diskusi. Bahkan juga sering dibicarakan oleh media massa, baik media elektronik maupun media cetak. Pernikahan mahasiswa masih banyak dijumpai semua negara berkembang termasuk Indonesia. Sampai saat ini, makin sering kita dengar fenomena pernikahan dini tidak hanya dikalangan masyarakat tradisional tetapi telah merambah pelajar dan mahasiswa. Resiko pernikahan mahasiswa rata-rata mereka banyak yang belum kerja. Namun pengakuan 
mereka menikah saat masih berstatus mahasiswa merupakan sebuah kebahagiaan tersendiri. "Kalau dulu makannya disiapin pedagang, sekarang disiapin orang tersayang," jelasnya. Apalagi kalau dia (istri) kelelahan. "Sekarang sudah ada yang tukang urut,". Dalam Undang-Undang No. 1 tahun1974 pasal 1 dinyatakan bahwa "perkawinan ialah ikatan lahir batin antara seorang wanita dan seorang pria sebagai suami istri dengan tujuan membentuk keluarga (rumah tangga) yang bahagia dan kekal berdasarkan ketuhanan Yang Maha Esa". ${ }^{1}$ Sedang dalam Kompilasi Hukum Islam "perkawinan yang sah menurut hukum Islam merupakan pernikahan, yaitu akad yang kuat atau mitsaqan ghalidzan untuk menaati perintah Allah dan melaksanakannya merupakan ibadah. ${ }^{2}$

Dari pengertian di atas, pernikahan memiliki tujuan membentuk keluarga yang bahagia dan kekal. Sehingga baik suami maupun istri harus saling melengkapi agar masing-masing dapat mengembangkan kepribadiannya membantu dan mencapai kesejahteraan spriritual dan material. ${ }^{3}$

Dalam Islam perkawinan dimaksudkan untuk memenuhi kebutuhan seksual seseorang secara halal serta untuk melangsungkan keturunannya dalam suasana saling mencintai (mawaddah) dan kasih sayang (rahmah) antara suami istri. Ini sesuai dengan bunyi pasal 3 Kompilasi Hukum Islam (KHI) yakni "perkawinan bertujuan untuk mewujudkan kehidupan rumah tangga yang sakinah mawaddah wa rohmah”. Jadi, pada dasarnya perkawinan merupakan cara penghalalan terhadap hubungan antar kedua lawan jenis, yang semula diharamkan, seperti memegang, memeluk, mencium dan hubungan intim.Allah SWT berfirmandalam surat Ar-Ruum ayat 21:

Artinya:" Dan di antara tanda-tanda kekuasaan-Nya ialah dia menciptakan untukmu isteri-isteri dari jenismu sendiri, supaya kamu cenderung dan merasa tenteram kepadanya, dan dijadikan-Nya diantaramu rasa kasih dan sayang. Sesungguhnya pada yang demikian itu benar-benar terdapat tanda-tanda bagi kaum yang berfikir”.(Q.S. Ar-Ruum: 21). ${ }^{4}$

\footnotetext{
${ }^{1}$ Tp, UU RI No. 1 Th. 1974 Tentang Perkawinan dan Kompilasi Hukum Islam (Cet. I; Yogyakarta: Pustaka Yustisia, 2008), hal. 7.

${ }^{2}$ Ibid, hal. 2.

${ }^{3}$ Ahmad Rofiq, Hukum Islam di Indonesia, (Jakarta: PT. Raja Grafindo Persada, 1995), hal. 56.

${ }^{4}$ Departemen Agama RI, Al-Qur'an dan Terjemahnya (Bandung: Gema Risalah Press, 1989), hal. 644.
} 
Perkawinan juga merupakan cara untuk melangsungkan kehidupan umat manusia di muka bumi, karena tanpa adanya regenerasi, populasi manusia di bumi ini akan punah. Dan perkawinan memiliki dimensi psikologis yang sangat dalam, karena dengan perkawinan ini kedua insan, suami dan istri, yang semula merupakan orang lain kemudian menjadi satu. Mereka saling memiliki, saling menjaga, saling membutuhkan, dan tentu saja saling mencintai dan saling menyayangi, sehingga terwujud keluarga yang harmonis (sakinah).$^{5}$

Pada hakikatnya pernikahan bukanlahhanya sebuah ikatan yang bertujuan untuk melegalkan hubungan biologis saja, namun juga untuk membentuk sebuah keluarga yang menuntut pelaku pernikahan untuk mandiri dalam berpikir dan menyelesaikan masalah dalam pernikahan. Pasangan suami istri harus menjalani proses kehidupan yang berorientasi pada kesuksesan bersama pasangan baik dunia maupun akhirat. ${ }^{6}$

Pernikahan yang saat ini sedang banyak berkembang di kalangan mahasiswa juga diharapkan mampu membawa pengaruh baik, seperti halnya dalam prestasi kampus dan kemampuan berhubungan dengan orang lain di sekitar kampus. Sehingga pernikahan usia mahasiswa mampu mendukung mahasiswa dalam meningkatkan kualitas diri dan daya saing di era modernisasi, baik dari segi akademis maupun sosial. Di sisi lain pernikahan usia mahasiswa diharapkan tidak mengganggu proses perkuliahan mahasiswa tersebut.

\section{PENGERTIAN PERNIKAHAN}

Agama Islam telah menetapkan bahwa satu-satunya jalan untuk memenuhi kebutuhan biologis manusia adalah hanya dengan pernikahan, pernikahan merupakan satu hal yang sangat menarik jika kita lebih mencermati kandungan makna tentang masalah pernikahan ini. Pernikahan adalah sunnah kauniah yang apabila dilaksanakan akan mendapat pahala tetapi apabila tidak dilakukan tidak mendapatkan dosa tetapi dimakruhkan karena tidak mengikuti sunnah rosul. ${ }^{7}$

\footnotetext{
${ }^{5}$ Masykuri Abdillah, "Distorsi Sakralitas Perkawinan Pada Masa Kini”, dalam Mimbar Hukum No. 36 Tahun IX 1998, hal. 74.

${ }^{6}$ Walgito, B. Bimbingan Konseling Dan Perkawinan. (Yogyakarta: Andi Offset, 2000), hal. 34.

${ }^{7}$ Syaikh Kamil Muhammad 'Uwaidah, Fiqih Wanita, (Jakarta: Pustaka al-Kautsar, 1998), hal. 375.
} 
Pernikahan merupakan sebuah perintah agama. Sedangkan di sisi lain adalah satu-satunya jalan penyaluran seks yang disahkan oleh agama. Dari sudut pandang ini, maka pada saat orang melakukan pernikahan pada saat yang bersamaan dia bukan saja memiliki keinginan untuk melakukan perintah agama, namun juga memiliki keinginan memenuhi kebutuhan biologisnya yang secara kodrat memang harus disalurkan. Adapun tujuan dari pernikahan yaitu ingin membangun keluarga yang sakinah mawaddah wa rohmah serta ingin mendapatkan keturunan yang solihah. Keturunan inilah yang selalu didambakan oleh setiap orang yang sudah menikah karena keturunan merupakan generasi bagi orang tuanya ${ }^{8}$

\section{HIKMAH PERNIKAHAN}

Pernikahan menjadikan proses keberlangsungan hidup manusia di dunia ini berlanjut, dari generasi ke generasi. Selain juga menjadi penyalur nafsu birahi, melalui hubungan suami istri serta menghindari godaan setan yang menjerumuskan. Pernikahan juga berfungsi untuk mengatur hubungan laki-laki dan perempuan berdasarkan pada asas saling menolong dalam wilayah kasih sayang dan penghormatan muslimah berkewajiban untuk mengerjakan tugas di dalam rumah tangganya seperti mengatur rumah, mendidik anak, dan menciptakan suasana yang menyenangkan. Supaya suami dapat mengerjakan kewajibannya dengan baik untuk kepentingan dunia dan akhirat. ${ }^{9}$

Adapun hikmah yang lain dalam pernikahannya itu yaitu :

a. Mampu menjaga kelangsungan hidup manusia dengan jalan berkembang biak dan berketurunan.

b. Mampu menjaga suami istri terjerumus dalam perbuatan nista dan mampu mengekang syahwat seta menahan pandangan dari sesuatu yang diharamkan.

c. Mampu menenangkan dan menentramkan jiwa dengan cara duduk-duduk dan bercengkerama dengan pacarannya.

d. Mampu membuat wanita melaksanakan tugasnya sesuai dengan tabiat kewanitaan yang diciptakan ${ }^{10}$

\footnotetext{
${ }^{8}$ Ahmad Rafi Baihaqi, Membangun Syurga Rumah Tangga, (Surabayah: Gita Mediah Press, 2006), hal. 8

${ }^{9}$ Syaikh Kamil Muhammad 'Uwaidah, Fiqih Wanita ....., hal. 378.

${ }^{10}$ Ahmad Rafi Baihaqi, Membangun Syurga Rumah Tangga, (Surabaya: Gita Mediah Press, 2006), hal. $10-12$.
} 


\section{HUKUM PERNIKAHAN}

Sebagaimana yang di jelaskan dalam Al-Qur'an Surat An-Nissa ayat 3

"Dan jika kamu takut tidak akan dapat Berlaku adil terhadap (hak-hak) perempuan yang yatim (bilamana kamu mengawininya), Maka kawinilah wanita-wanita (lain) yang kamu senangi : dua, tiga atau empat. kemudian jika kamu takut tidak akan dapat Berlaku adil. Maka (kawinilah) seorang saja, atau budak-budak yang kamu miliki. yang demikian itu adalah lebih dekat kepada tidak berbuat aniaya.'(An-Nisaa', 3)

Dari keterangan diatas disimpulkan bahwa hukum nikah ada 5 :

a. Wajib kepada orang yang mempunyai nafsu yang kuat sehingga bisa menjerumuskannya ke lembah maksiat (zina dan sebagainya) sedangkan ia seorang yang mampu. Di sini mampu bermaksud ia mampu membayar mahar (mas perkawinan/dower) dan mampu memberi nafkah kepada calon istrinya. Bagi orang yang telah mempunyai kemauan dan kemampuan untuk menikah dan dikhawatirkan akan tergelincir pada perbuatan zina seandainya tidak menikah maka hukum melakukan pernikahan bagi orang tersebut adalah wajib. Hal ini didasarkan pada pemikiran hukum bahwa setiap muslim wajib menjaga diri untuk tidak berbuat yang terlarang. Jika penjagaan diri itu harus dengan melakukan pernikahan, sedang menjaga diri itu wajib, maka hukum melakukan pernikahan itupun wajib sesuai kaidah:

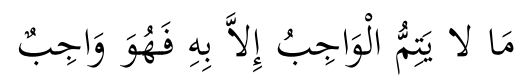

Artinya: ,Sesuatu yang wajib tidak sempurna kecuali dengannya, maka sesuatu itu hukumnya wajib juga

Kaidah lain mengatakan:

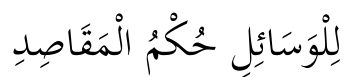

Artinya: Sarana itu hukumnya sama dengan hukum yang dituju.

Hukum melakukan pernikahan bagi orang tersebut merupakan hukum sarana sama dengan hukum pokok yakni menjaga diri dari perbuatan maksiat.

b. Sunat kepada orang yang mampu tetapi dapat mengawal nafsunya. 
Orang yang telah mempunyai kemauan dan kemampuan untuk melangsungkan pernikahan, tetapi kalau tidak menikah tidak dikhawatirkan akan berbuat zina, maka hukum melakukan pernikahan bagi orang tersebut adalah sunah. Alasan menetapkan hukum sunah itu ialah dari anjuran Al Quran seperti tersebut dalam surat An Nur ayat 32 dan hadis nabi yang diriwayatkan Bukhari dan Muslim dari Abdullah bin Mas'ud yang dikemukakan dalam menerangkan sikap agama Islam terhadap pernikahan. Baik ayat Al Quran maupun As Sunnah tersebut berbentuk perintah, tetapi berdasarkan qarinah-qarinah yang ada, perintah nabi tidak menfaidahkan hukum wajib, tetapi hukum sunah saja.

c. Harus kepada orang yang tidak ada padanya larangan untuk berkawin dan ini merupakan hukum asal perkawinan

d. Makruh kepada orang yang tidak berkemampuan dari segi nafkah batin dan lahir tetapi sekadar tidak memberi kemudaratan kepada isteri. Artinya Bagi orang yang mempunyai kemampuan untuk melakukan pernikahan juga cukup mempunyai kemampuan untuk menahan diri sehingga tidak memungkinkan dirinya tergelincir berbuat zina sekiranya tidak menikah. Hanya saja orang ini tidak mempunyai keinginan yang kuat untuk dapat memenuhi kewajiban suami istri dengan baik.

e. Melakukan Pernikahan yang Hukumnya Mubah

Bagi orang yang mempunyai kemampuan untuk melakukannya, tetapi apabila tidak melakukannya tidak khawatir akan berbuat zina dan apabila melakukannya juga tidak akan menelantarkan istri. Pernikahan orang tersebut hanya didasarkan untuk memenuhi kesenangan bukan dengan tujuan menjaga kehormatan agamanya dan membina keluarga sejahtera. Hukum mubah ini juga ditujukan bagi orang yang antara pendorong dan penghambatnya untuk menikah itu sama, sehingga menimbulkan keraguan orang yang akan melakukan pernikahan, seperti mempunyai keinginan tetapi belum mempunyai keinginan, mempunyai kemampuan untuk melakukan tetapi belum mempunyai kemauan yang kuat. 
f. Haram kepada orang yang tidak berkempuan untuk memberi nafkah batin dan lahir dan ia sendiri tidak berkuasa (lemah), tidak punya keinginan menikah serta akan menganiaya isteri jika dia menikah. ${ }^{11}$ Artinya Bagi orang yang tidak mempunyai keinginan dan tidak mempunyai kemampuan serta tanggungjawab untuk melaksanakan kewajiban-kewajiban dalam rumah tangga sehingga apabila melangsungkan pernikahan akan terlantarlah dirinya dan istrinya, maka hukum melakukan pernikahan bagi orang tersebut adalah haram. Al Quran surat Al Baqarah ayat 195 melarang orang melakukan hal yang akan mendatangkan kerusakan:

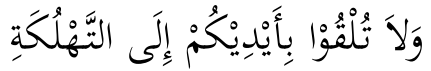

Artinya: ,Dan janganlah kamu menjatuhkan dirimu sendiri ke dalam kebinasaan.

Termasuk juga hukumnya haram pernikahan bila seseorang menikah dengan maksud untuk menelantarkan orang lain, masalah wanita yang dinikahi itu tidak diurus hanya agar wanita itu tidak dapat menikah dengan orang lain.

\section{TUJUAN PERNIKAHAN}

Berbicara mengenai tujuan pernikahan atau tujuan perkawinan, kedua belah pihak antara laki-laki dan perempuan melangsungkan pernikahan atau perkawinan bertujuan untuk memperoleh keluarga yang sakinah, mawadah dan rahmah. Untuk mengetahui lebih jelas mengenai tujuan pernikahan akan dibahas sebagai berikut.

\section{a. Tujuan Pernikahan Sakinah (tenang)}

Salah satu dari tujuan pernikahan atau perkawinan adalah untuk memperoleh keluarga yang sakinah. Sakinah artinya tenang, dalam hal ini seseorang yang melangsungkan pernikahan berkeinginan memiliki keluarga yang tenang dan tentram. Dalam Tafsirnya, Al-Alusi mengatakan bahwa sakinah adalah merasa cenderung kepada pasangan. Kecenderungan ini merupakan satu hal yang wajar karena seseorang pasti akan merasa cenderung terhadap dirinya.

\footnotetext{
${ }^{11}$ Muhammad At-tihami, Merawat Cintah Kasih Menurut Syriat Islam, (Surabaya : Ampel Mulia, 2004), hal. 18.
} 
Apabila kecenderungan ini disalurkan sesuai dengan aturan Islam maka yang tercapai adalah ketenangan dan ketentraman, karena makna lain dari sakinah adalah ketenangan. Ketenangan dan ketentraman ini yang menjadi salah satu dari tujuan pernikahan atau perkawinan. Karena pernikahan adalah sarana efektif untuk menjaga kesucian hati agar terhindar dari perzinahan.

\section{b. Tujuan Pernikahan Mawadah dan Rahmah}

Tujuan pernikahan yang selanjutnya adalah untuk memperoleh keluarga yang mawadah dan rahmah. Tujuan pernikahan Mawadah yaitu untuk memiliki keluarga yang di dalamnya terdapat rasa cinta, berkaitan dengan hal-hal yang bersifat jasmaniah. Tujuan pernikahan Rahmah yaitu untuk memperoleh keluarga yang di dalamnya terdapat rasa kasih sayang, yakni yang berkaitan dengan hal-hal yang bersifat kerohanian.

Mengenai pengertian mawaddah menurut Imam Ibnu Katsir ialah al mahabbah (rasa cinta) sedangkan ar rahmah adalah ar-ra'fah (kasih sayang). Mawaddah adalah makna kinayah dari nikah yaitu jima' sebagai konsekuensi dilangsungkannya pernikahan. Sedangkan ar rahmah adalah makna kinayah dari keturunan yaitu terlahirnya keturunan dari hasil suatu pernikahan. Ada juga yang mengatakan bahwa mawaddah hanya berlaku bagi orang yang masih muda sedangkan untuk ar-rahmah bagi orang yang sudah tua.

\section{c. Implementasi dari tujuan pernikahan}

mawaddah wa rahmah ini adalah sikap saling menjaga, saling melindungi, saling membantu, saling memahami hak dan kewajiban masing-masing. Pernikahan adalah lambang dari kehormatan dan kemuliaan. Fungsi pernikahan diibaratkan seperti fungsi pakaian, karena salah satu fungsi pakaian adalah untuk menutup aurat. Aurat sendiri bermakna sesuatu yang memalukan, karena memalukan maka wajib untuk ditutup. Dengan demikian seharusnya dalam hubungan suami istri, satu sama lainnya harus saling menutupi kekurangan pasangannya dan saling membantu untuk mempersembahkan yang terbaik. ${ }^{12}$

\footnotetext{
12 ABD. Shomad, Hukum Islam (Penormaan Prinsip Syariah dalam Hukum Indonesia). (Jakarta: Penerbit Kencana (Prenada Media Group : Jakarta. 2010), hal 45.
} 


\section{SYARAT MENIKAH}

Syarat adalah sesuatu yang mesti ada yang menentukan sah atau tidaknya suatu pekerjaan (ibadah), tetapi sesuatu itu tidak termasuk dalam rangkaian pekerjaan tersebut. Adapun syarat sah dalam pernikahan sebagai berikut: ${ }^{13}$

a. Calon suami Seorang calon suami yang akan menikah harus memenuhi syarat-syarat sebagai berikut:
a) Bukan mahram dari calon istri
b) Tidak terpaksa (atas kemauan sendiri)
c) Jelas orangnya (bukan banci)
d) Tidak sedang ihram haji

b. Calon istri

Bagi calon istri yang akan menikah juga harus memenuhi syarat syarat sebagai berikut:
a) Tidak bersuami
b) Bukan mahram
c) Tidak dalam masa iddah
d) Merdeka (atas kemauan sendiri)
e) Jelas orangnya
f) Tidak sedang ihram haji

b. Wali

Untuk menjadi seorang wali dalam sebuah pernikahan, harus memenuhi syarat-syarat sebagai berikut:
a) Laki-laki
b) Dewasa
c) Waras akalnya
d) Tidak dipaksa
e) Adil
f) Tidak sedang ihram haji

${ }^{13}$ Al Hamdani, Risalah Nikah Hukum Perkawinan Islam, Cet. 2, (Jakarta: Pustaka Amani, 2002), hal. 6768. 
c. Ijab kabul

Ijab adalah sesuatu yang diucapkan oleh wali, sedangkan kabul ialah sesuatu yang diucapkan oleh mempelai pria atau wakilnya disaksikan oleh dua orang saksi.

d. Mahar

Mahar adalah pemberian dari calon mempelai pria kepada calon mempelai wanita, baik dalam bentuk barang atau jasa yang tidak bertent angan dengan hukum Islam. ${ }^{14}$ Fuqaha sependapat bahwa maskawin itu termasuk syarat sahnya nikah dan tidak boleh diadakan persetujuan untuk meniadakannya ${ }^{15}$

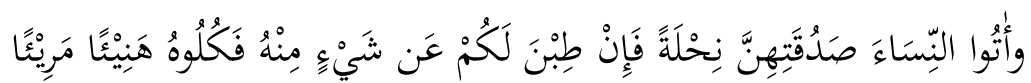

Artinya : Berikanlah maskawin (mahar) kepada wanita (yang kamu nikahi) sebagai pemberian dengan penuh kerelaan. Kemudian jika mereka menyerahkan kepada kamu sebagian dari maskawin itu dengan senang hati, maka makanlah (ambillah) pemberian itu (sebagai makanan) yang sedap lagi baik akibatnya. (QS. An Nisa':4) ${ }^{16}$

Di dalam KHI Pasal 30 dijelaskan dengan tegas bahwa: calon mempelai pria wajib membayar mahar kepada calon mempelai wanita yang jumlah, bentuk dan jenisnya disepakati oleh kedua belah pihak. ${ }^{17}$ Yaitu untuk memperoleh kebahagiaan dan kesejahteraan lahir batin menuju kebahagiaan dan kesejahteraan akhirat.

\section{RUKUN PERNIKAHAN}

Rukun adalah sesuatu yang harus ada untuk menentukan sah atau tidaknya suatu pekerjaan (ibadah), namun sesuatu itu termasuk dalam rangkaian pekerjaan tersebut. Adapun rukun dalam sebuah pernikahan, jumhur ulama sepakat ada empat, yaitu: ${ }^{18}$

a. Adanya calon suami dan istri yang akan melakukan pernikahan. Syarat-syarat yang harus dipenuhi oleh kedua mempelai adalah:

\footnotetext{
${ }^{14}$ Abdurrahman, Kompilasi Hukum Islam, Edisi I, (Jakarta: Akademika Pressindo, 1992), hal. 113.

${ }^{15}$ Ibnu Rusyd, Bidayatul Mujtahid wa Nihayatul Muqtasid, Cet. 2, Terj. Imam Ghazali Sa'id dan Ahmad Zaidun, (Jakarta: Pustaka Amani, 2002), hal. 432.

${ }^{16}$ Departemen Agama RI, Al Quran Tajwid dan Terjemahnya, hal. 115.

${ }^{17}$ Abdurrahman, Kompilasi Hukum Islam ...., hal. 120.

${ }^{18}$ Abd. Rahman Ghazaly, Fikih Munakahat, hal. 46.
} 
a) Laki-laki dan perempuan yang melangsungkan pernikahan haruslah sama-sama beragama Islam.

b) Keduanya harus jelas identitasnya dan bisa dibedakan dengan orang lain, baik terkait dengan nama, keberadaan, jenis kelamin dan hal-hal lainnya yang berkenaan dengan dirinya. Dengan adanya syariat peminangan sebelum berlangsungnya pernikahan kiranya merupakan suatu syarat supaya kedua calon mempelai bisa sama-sama tahu dan mengenal satu sama lain secara baik dan terbuka.

c) Kedua belah pihak telah setuju untuk menikah dan juga setuju dengan pihak yang mengawininya. Tentang izin dan persetujuan ari kedua belah pihak yang akan melangsungkan pernikahan ulama fikih berbeda pendapat dalam menyikapinya.

Sedangkan dalam Kompilasi Hukum Islam ditegaskan mengenai persyaratan persetujuan kedua mempelai pada pasal 16, yaitu:

(a) Perkawinan didasarkan atas persetujuan calon mempelai.

(b) Bentuk persetujuan calon mempelai wanita berupa pernyataan tegas dan nyata dengan tulisan, lisan, atau isyarat tapi dapat juga dengan berupa diam dalam arti selama tidak ada penolakan yang tegas.

(c) Antara kedua belah pihak tidak ada hal-hal yang terlarang untuk melangsungkan pernikahan.

(d) Kedua belah pihak telah mencapai usia yang pantas dan layak untuk melangsungkan pernikahan. Untuk syarat yang terakhir ini akan dibahas sendiri pada penjelasan selanjutnya.

b. Adanya wali dari pihak calon pengantin wanita. Akad nikah dianggap sah apabila ada seorang wali atau wakilnya yang akan menikahkannya, sabda Nabi saw.:

Artinya: Diriwayatkan dari Hasan dari Ibn Lahi'ah dari Ja'far ibn Rabi'ah dari Ibn Syihab dari 'Urwah ibn al-Zubair dari 'Aisyah berkata: Rasulullah SAW bersabda: Perempuan mana saja yang menikah tanpa seizin walinya maka pernikahannya batal. Jika suaminya telah menggaulinya, maka maskawinnya adalah untuknya (wanita) terhadap apa yang diperoleh 
darinya. Apabila mereka bertengkar, maka penguasa menjadi wali bagi mereka yang tidak mempunyai wali. (HR. Ahmad). ${ }^{19}$

Syarat-syarat yang harus dipenuhi oleh seseorang yang menjadi wali adalah:

a) Orang merdeka (bukan budak)

b) Laki-laki (bukan perempuan) sebagaimana yang dijelaskan dalam hadis yang diriwayatkan Abu Hurairah. Namun ulama Hanafiah dan Syiah Imamiyah berbeda pendapan tentang hal ini. Keduanya berpendapat bahwa perempuan yang telah dewasa dan berakal sehat dapat menjadi wali untuk dirinya sendiri dan dapat pula menjadi wali untuk perempuan lain yang mengharuskan adanya wali.

c) Telah dewasa dan berakal sehat. Oleh karena itu anak kecil atau orang gila tidak berhak menjadi wali. Hal ini merupakan syarat umum bagi seseorang yang melakukan akad.

d) Tidak sedang melakukan ihram untuk haji atau umrah. Hal ini berdasarkan hadis Nabi dari Usman menurut riwayat Abu Muslim yang artinya ,Orang yang sedang ihram tidak boleh menikahkan seseorang dan tidak boleh pula dinikahkan oleh seseorang.

e) Tidak dalam keadaan mendapat pengampuan (mahjur 'alaih). Hal ini karena orang yang berada di bawah pengampuan tidak dapat berbuat hukum dengan dirinya sendiri.

f) Adil dalam arti tidak pernah terlibat dengan dosa besar dan tidak sering terlibat dengan dosa kecil serta tetap memelihara murah dan sopan santun. Hadis Nabi dari 'Aisyah menurut riwayat Al Quṭi menjelaslan bahwa ,Tidak sah nikah kecuali bila ada wali dan dua orang saksi yang adil.

g) Berpikiran baik. Oleh karena itu tidak sah menjadi wali seseorang yang terganggu pikirannya sebab ketuaannya, karena dikhawatirkan tidak akan mendatangkan maslahat dalam pernikahan tersebut.

\footnotetext{
${ }^{19}$ Sayyid Abu Al Ma'aathiy An Nuriy, Kitab Baqi’ Musnad Ahmad, ('Amman: Dar'Alamil Kutub, 1419), hal. 232-236.
} 
h) Seorang muslim, oleh karena itu orang yang tidak beragama Islam tidak sah menjadi wali untuk pernikahan muslim. Allah berfirman dalam surat Ali Imran ayat 28:

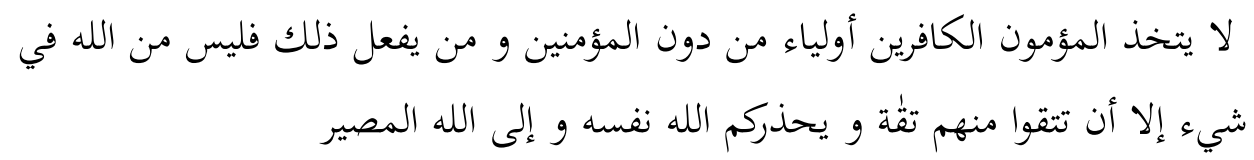
Artinya: Janganlah orang-orang mukmin mengambil orang-orang kafir menjadi wali dengan meninggalkan orang-orang mukmin. barang siapa berbuat demikian, niscaya lepaslah ia dari pertolongan Allah, kecuali karena (siasat) memelihara diri dari sesuatu yang ditakuti dari mereka. dan Allah memperingatkan kamu terhadap diri (siksa)-Nya. dan Hanya kepada Allah kembali (mu). (QS. Ali Imran: 28). ${ }^{20}$

c. Adanya dua orang saksi

Ada perbedaan pendapat dikalangan ulama tentang kedudukan saksi dalam pernikahan, apakah termasuk rukun ataukah termasuk syarat dalam pernikahan. Ulama Syafi'iyah dan Hana bilah berpendapat bahwa saksi itu adalah termasuk rukun dari pernikahan. Sedangkan menurut Hanafiyah dan Zahiriyah, saksi merupakan salah satu dari dari syarat-syarat pernikahan yang ada. Tentang keharusandanya saksi dalam akad pernikahan dijelaskan dalam Al Quran surat Al Talaq ayat 2

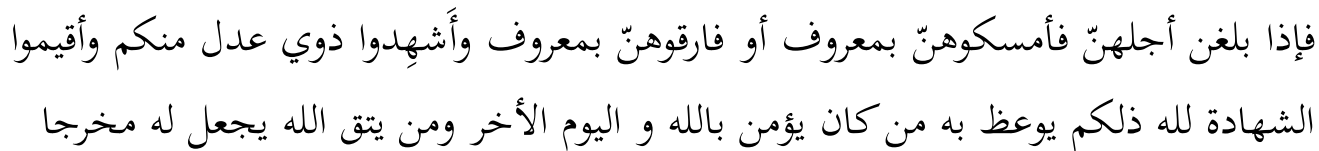
Artinya: Apabila mereka Telah mendekati akhir iddahnya, Maka rujukilah mereka dengan baik atau lepaskanlah mereka dengan baik dan persaksikanlah dengan dua orang saksi yang adil di antara kamu dan hendaklah kamu tegakkan kesaksian itu Karena Allah. Demikianlah diberi pengajaran dengan itu orang yang beriman kepada Allah dan hari akhirat. barangsiapa bertakwa kepada Allah niscaya dia akan mengadakan baginya jalan keluar. (QS. Al T alāq: 2). ${ }^{21}$

\footnotetext{
${ }^{20}$ Departemen Agama RI, Al Quran Tajwid dan Terjemahannya, 80.

${ }^{21}$ Ibid, hal. 945.
} 
Tidak semua orang boleh menjadi saksi, khususnya dalam pernikahan. Ada beberapa syarat yang harus dipenuhi agar dia bisa menjadi saksi yang sah, yaitu:

a) Saksi berjumlah minimal dua orang. Pendapat inilah yang dipegang oleh jumhur ulama. Sedangkan hanāfiyah berpendapat lain, menurutnya, saksi itu boleh terdiri dari satu orang laki-laki dan dua orang perempuan.

b) Kedua saksi itu merdeka (bukan budak).

c) Saksi bersifat adil dalam arti tidak pernah melakukan dosa besar dan tidak selalu melakukan dosa kecil dan tetap menjaga muruah.

d) Saksi harus beragama Islam.

e) Saksi harus bisa mendengar dan melihat.

f) Kedua saksi adalah laki-laki. Menurut Hanafiyah saksi itu boleh terdiri dari perempuan asalkan harus disertai saksi dari laki-laki. Sedangkan menurut Zahiriyah, saksi boleh dari perempuan dengan pertimbangan dua orang perempuan sama kedudukannya dengan seorang laki-laki.

c. Sighat akad nikah yaitu ijab dan kabul yang diucapkan oleh wali atau wakilnya dari pihak wanita dan dijawab oleh calon pengantin laki-laki. Dalam hukum Islam, akad pernikahan itu bukanlah sekedar perjanjian yang bersifat keperdataan. Akad dinyatakan sebagai perjanjian yang kuat yang disebut dengan ungkapan misaqan galizan dalam Al Quran, yang mana perjanjian itu bukan haya disaksikan oleh dua orang saksi atau kehadiran orang banyak pada waktu terlangsungnya pernikahan, akan tetapi juga disaksikan langsung oleh Allah SWT. Oleh karena itu perjanjian pada akad pernikahan ini sangatlah bersifat agung dan sakral.

Ada beberapa syarat yang harus dipenuhi agar akad ijab kabul itu bisa menjadi sah, yaitu:

a) Akad dimulai dengan ijab dan dilanjutkan dengan kabul. Ijab berarti penyerahan dari pihak pertama, sedangkan Kabul adalah penerimaan dari pihak kedua. Contoh penyebutan ijab ,saya nikahkan anak saya yang bernama Khotibah dengan mahar uang satu juta rupiah dibayar tunaie . Lalu kabulnya ,saya terima menikahi anak bapak yang bernama Khotibah 
dengan mahar uang sebesar satu juta rupiah. Materi dari ijab dan Kabul tidak boleh berbeda, seperti nama si perempuan dan bentuk mahar yang sudah ditentukan.

b) Ijab dan Kabul harus menggunakan lafad yang jelas dan terang sehingga dapat dipahami oleh kedua belah pihak secara tegas. Dalam akad tidak boleh menggunakan kata sindiran karena masih dibutuhkan sebuah niat, sedangkan saksi dalam pernikahan itu tidak akan dapat mengetahui apa yang diniatkan oleh seseorang. Lafad yang sharih (terang) yang disepakati oleh ulama ialah kata nakaha atau zawaja, atau terjemahan dari keduanya.

c) Ijab dan kabul tidak boleh dengan menggunakan ungkapan yang bersifat membatasi masa berlangsungnya pernikahan, karena adanya pernikahan itu bertujuan untuk selama hidupnya, bukan sesaat saja.

d) Ijab dan kabul harus diucapkan secara bersinambungan tanpa terputus walau sesaat. ${ }^{22}$

\section{PEMBATALAN PERNIKAHAN}

Menurut hukum Islam suatu pernikahan dapat batal atau fasid. Pernikahan yang melanggar larangan yang bersifat abadi, yakni yang berkaitan dengan hukum agama dalam pernikahan, maka pembatalannya bersifat abadi. Sedang yang melanggar larangan yang bersifat sementara, yakni larangan yang adakalanya berhubungan dengan hukum agama, kemaslahatan dan administrasi, maka pembatalannya bersifat sementara. Untuk mengetahui sampai sejauh mana akibat hukum suatu akad nikah, maka perlu diketahui status hukum akad nikah yang dilangsungkan itu sehubungan Jika suatu akad pernikahan telah memenuhi segala rukun syaratnya secara lengkap menurut yang telah ditentukan, maka akad pernikahan yang demikian itu disebut akad pernikahan yang sah dan berakibat hukum, yakni:

a. Kehalalan hubungan seksual antara suami istri.

b. Tetapnya hak mahar bagi istri menurut prosedur yang telah ditetapkan.

c. Timbulnya hak dan kewajiban selaku suami istri.

d. Tetapnya nasab anak yang dilahirkan oleh istri bagi suami.

\footnotetext{
${ }^{22}$ Amir Syarifuddin, Hukum Perkawinan Islam di Indonesia, hal. 62.
} 
e. Keterbatasan keleluasaan istri.

f. Timbulnya larangan kawin bagi istri yang terikat oleh tali pernikahan atau sebelum beriddah setelah bercerai atau ditinggal mati oleh suaminya.

Jika suatu akad pernikahan kurang satu atau beberapa rukun atau syarat disebut pernikahan yang tidak sah. Tidak sahnya suatu akad pernikahan dapat terjadi sebab tidak dipenuhinya salah satu di antara rukun-rukunnya disebut akad pernikahan yang batal, dan dapat pula terjadi sebab tidak dipenuhi salah satu syaratnya disebut akad pernikahan yang fasid.

\section{MANFAAT NIKAH MENURUT KESEHATAN}

Menikah bisa membuat seseorang terhindar dari penyakit berbahaya dan juga stres. Mengutip Reader's Digest, setidaknya ada 10 manfaat menikah bagi kesehatan. Sebagaimana firman Allah dalam surat An Nisa' ayat 4:

\section{a. Menurunkan risiko demensia}

Ada banyak kebiasaan sehari-hari yang menurunkan risiko penyakit Alzheimer, yang mempengaruhi satu dari tiga lansia. Tapi Anda bisa secara signifikan menurunkan risiko itu dan melindungi otak Anda dengan menikah. Sebuah studi baru menunjukkan bahwa pria dan wanita yang sudah menikah memiliki kemungkinan $43 \%$ lebih rendah menderita demensia saat mereka menua.

\section{b. Tekanan darah membaik}

Penyakit jantung adalah pembunuh nomor satu di Amerika, namun menikah dapat mengurangi risiko tersebut. Menurut sebuah studi yang dilakukan oleh Universitas Brigham Young, orang yang sudah menikah memiliki pembacaan tekanan darah rendah daripada rekan merka yang tetap melajang. Periset memantau tekanan darah selama 24 jam dan menemukan bahwa, rata-rata, pasangan yang sudah menikah dan bahagia memiliki tekanan darah yang baik.

\section{c. Kehidupan seks Anda akan menjadi panas}

Menikah akan membuat kehidupan bercinta anda lebih nikmat. Berdasarkan survei Kesehatan dan Kehidupan Sosial Nasional, ditemukan bahwa 51\% pasangan suami-istri mengtakakan bahwa mereka "sangat puas" dengan 
kehidupan seks mereka dibandingkan dengan 39\% orang yang tinggal bersama dan $36 \%$ yang single.

\section{d. Terhindar dari stres}

Stres terkait dengan semua jenis masalah kesehat an yang menakutkan termasuk diabetes, penyakit jantung, dan kanker. Namun orang-orang yang sudah menikah memiliki perlindungan terhadap stres sehari-hari. Menurut sebuah penelitian yang diterbitkan dalam The Journal of Marriage and Family, pernikahan yang bahagia akan menghindarkan pasutri dari stres. Perkawinan yang tidak bahagia, karena alasan yang jelas, membuat stres semakin buruk.

\section{e. Menyehatkan paru-paru}

Siapa yang tidak menyukai perasaan bisa menghirup udara segar? Seiring bertambahnya usia, semakin banyak ditemukan pentingnya paru-paru yang sehat. Dan berada dalam hubungan jangka panjang - termasuk pernikahan dan pengaturan sosial lainnya - memperbaiki fungsi paru-paru pada manula.

\section{f. Bertahan dari kanker}

Menikah tampaknya tidak mengurangi risiko terkena kanker, tapi, hal tersebut memberi peluang lebih baik untuk bertahan, demikian menurut penelitian yang dipublikasikan di jurnal CANCER. Para ilmuwan melihat catatan medis lebih dari 800.000 orang dan menemukan bahwa pria lajang memiliki kesempatan $27 \%$ lebih tinggi dan wanita lajang memiliki kesempatan 19\% lebih tinggi meninggal setelah diagnosis kanker.

\section{g. Menyehatkan jantung}

Pernikahan tidak hanya menurunkan tekanan darah Anda, tapi juga meningkatkan kesehatan jantung secara keseluruhan. Hal itu berdasarkan penelitian yang diterbitkan di European Journal of Preventive Cardiology.

\section{h. Memperpanjang usia}

Pria yang sudah menikah memiliki kesehatan fisik yang lebih baik dan umur yang lebih panjang, rata-rata hidup sepuluh tahun lebih lama dari pria lajang, menurut penelitian sebelumnya. Satu alasan yang mungkin berkaitan dengan efek menikah terhadap kesehatan finansial mereka adalah karena pendapatan merupakan prediktor angka satu kesehatan. 


\section{i. Baik untuk kesehatan mental}

Pria yang sudah menikah bisa mendapatkan manfaat lebih banyak. Namun wanita yang sudah menikah lebih bahagia selama hari-hari mereka. (Plus, wanita pada umumnya masih hidup lebih lama dari laki-laki.) Perempuan dalam pernikahan bahagia mengalami lebih sedikit insiden depresi, kecemasan dan penyakit jiwa lainnya daripada wanita lajang. Memiliki dukungan sosial yang konstan dari suami mereka membantu wanita tetap sehat.

\section{j. Gaya hidup jadi lebih sehat}

Dalam hampir semua ukuran kesehatan, para periset telah menemukan bahwa pasangan yang menikah, pasangannya berpakaian lebih baik. Bagian dari itu adalah karena semua alasan di atas, namun sebagian dari itu mungkin karena orang-orang dalam hubungan jangka panjang tampaknya membuat pilihan yang lebih sehat. ${ }^{23}$

\section{PEMBAHASAN}

Menikah memang merupakan bagian dari fitrah seorang manusia baik itu lakilaki maupun perempuan. Dan adalah hal yang wajar jika teman-teman yang masih kuliah sudah punya hasrat untuk menikah. Menikah yang akan dibahas di sini adalah karena hal yang wajar bukan karena kecelakaan duluan sebelum menikah. ${ }^{24}$ Kita kembali ke pembahasan, mahasiswa-mahasiswi yang masih kuliah tapi sudah menginginkan menikah.

Menghadapi hal tersebut, pertimbangannya akan berbeda untuk setiap orang. Tergant ung kesiapan mental dan finansial yang ada, penerimaan orang tua dan keluarga, beban kuliah di kampus juga lingkungan sosial sekitar kampus. Oleh karena itu, tulisan ini akan memberikan saran secara umum dengan asumsi bahwa kuliah teman-teman adalah prioritas.

\footnotetext{
${ }^{23}$ Rina Anggraeni - Reportase Jurnalistik - 207, 6 Tips Buat Teman Jatuh Cinta. Pengalaman ... Fans Hitung Mundur Pernikahan

${ }^{24}$ zina adalah dosa yang sangat besar dan sangat keji, serta seburuk-buruk jalan yang ditempuh oleh seseorang; berdasarkan firman Allah Subhanahu wa Ta'ala Dan janganlah kamu mendekati zina, karena sesungguhnya zina itu adalah faahisah (perbuatan yang keji) dan seburuk-buruk jalan (yang ditempuh oleh seseorang). [al Israa//17:32].
} 
1. Sebaiknya, tunda pernikahan sampai memiliki penghasilan

Saran pertama, sebaiknya tunda pernikahan teman-teman sampai memiliki penghasilan sendiri. Terutama ini lebih ditekankan bagi teman-teman yang laki-laki. Karena laki-laki punya tanggung jawab untuk memberi nafkah dan membantu secara finansial sang istri. Kami sarankan untuk memiliki penghasilan, bukan pekerjaan. Karena konotasi bekerja diasumsikan sudah pakai seragam, masuk kantor dan punya atasan. Tetapi memiliki penghasilan tidak harus memiliki kantor dan seragam atau jam kerja. Apa lagi zaman sekarang, hanya bermodal laptop teman-teman sudah bisa memperoleh penghasilan. Misalnya menjadi penulis buku atau novel. Menjadi penulis freelance, desain grafis dan sebagainya. Apalagi jika plus jaringan internet, teman-teman sudah bisa mendapatkan penghasilan yang lebih hebat melalui affiliate program, menjual online course atau sistem dropship. Berapa penghasilan yang disarankan? Tidak ada angka atau nominal khusus. Tapi minimal cukup untuk makan berdua sebulan, biaya kontrakan atau kost dan cicilan SPP kuliah. Supaya lebih ringan, temanteman bisa menunggu salah satu lulus terlebih dahulu, supaya biaya untuk SPP kuliah lebih ringan. Jadi saran pertama yang kami anjurkan, sebaiknya tunggu sampai memiliki penghasilan dan salah satunya lulus dan memiliki penghasilan.

2. Tunda pernikahan, minimal sampai lulus kuliah.

Kadang, mendapatan penghasilan sejak masih kuliah bukan perkara gampang. Tidak semua orang bisa memperolehnya. Bisa karena hambatan kesibukan kuliah, keterbatasan sarana transportasi atau alasan lainnya. Bagi teman-teman yang belum mendapatkan penghasilan sebelum kuliah, sebaiknya tunda pernikahan sampai keduanya benar-benar lulus. Agar setidaknya, kita tidak perlu memikirkan biaya dan tugas-tugas kuliah. Urusan biaya kuliah menjadi pertimbangan karena jangan sampai setelah menikah kuliah jadi berantakan bahkan jadi DO (Drop Out). Padahal seharusnya kuliah menjadi lebih bersemangat setelah menikah. Prestasi dan nilai IPK bisa lebih terpacu karena ada yang membantu jika kesulitan dan 
menenangkan jika sedang stress dengan urusan kampus. Namun jika temanteman adalah pihak perempuan, hal ini tidak terlalu menjadi masalah, karena tidak bertanggung jawab untuk memberi nafkah dan biaya hidup keluarga. Kecuali jika ternyata, teman-teman hamil ketika masih kuliah. Sah-sah saja sih. Tapi akan sangat kerepotan, walaupun bisa ambil cuti kuliah. Walaupun berjanji berusaha agar tidak hamil saat masih kuliah. Tapi, siapa tahan?! Jadi, jika teman-teman masih mampu menahan dorongan untuk menikah sampai mendapat penghasilan dan lulus kuliah, itu insyaAllah yang paling baik. Jika tidak tahan, maka minimal tunggulah sampai lulus kuliah.

3. Tidak tahan, minimal sampai semester akhir kuliah.

Sekali lagi, menahan tidak menikah sampai lulus kuliah adalah pilihan paling minimal, paling terpaksa. Tapi pada kondisi dan pertimbangan tertentu, boleh-boleh saja sedikit bertoleransi, yaitu menikah pada semester-semester akhir, semisal mulai semester 6 ke atas. Apa saja pertimbangannya? Pertama, teman-teman sudah benar-benar memperhitungkan dari mana biaya makan, kontrakan dan biaya kuliah di sisa semester yang akan ditempuh. Memperhitungkan artinya benar-benar ada sumber biayanya, bukan masih diusahakan atau masih difikirkan. Ini jika teman-teman sebagai pihak laki-laki. Kedua, teman-teman harus memperhitungkan bagaimana jika ternyata hamil ketika kuliah belum selesai. Walaupun bisa diatur atau dihindari dengan berbagai cara dan metode. Tapi, siapa tahan?! Apa lagi pengantin baru. Ini jika teman-teman sebagai pihak perempuan. Termasuk bagaimana jika harus mengambil cuti kuliah dan bagaimana merawat bayi kalian. Diasuh sendiri, gantian, menyewa pengasuh atau dititipkan mertua? Ketiga, beban studi sudah tidak terlalu berat dan tidak terlalu sering ke kampus. Maksudnya agar temanteman, terutama pihak laki-laki memiliki lebih banyak waktu untuk mencari tambahan penghasilan. Terutama bagi yang belum memiliki pekerjaan tetap dan mencukupi. Keempat, keluarga laki-laki dan perempuan benar-benar mendukung teman-teman mengambil keputusan tersebut. Kedua keluarga 
harus mendukung agar kesulitan-kesuitan yang muncul, baik urusan kuliah ataupun yang lainnya dapat dibantu. Apalagi teman-teman yang memutuskan segera menikah selagi kuliah adalah keluarga baru yang belum memiliki pengalaman menghadapi permasalahan rumah tangga. ${ }^{25}$

\section{KESIMPULAN}

Dari beberapa kajian teori dan beberapa pembahasan, maka penulis dapat menyimpulkan sebagai berikut:

1. Hukum Menikah Bagi Mahasiswa, Sedang Dia Masih Dapat Menjaga Dirinya. Mahasiswa yang masih kuliah, berarti mereka sedang menjalani suatu kewajiban, yaitu menuntut ilmu. Sedangkan menikah hukum asalnya adalah tetap sunnah baginya, tidak wajib, selama dia masih dapat memelihara kesucian jiwa dan akhlaqnya, dan tidak sampai terperosok kepada yang haram meskipun tidak menikah. Karena itu, dalam keadaan demikian harus ditetapkan kaidah aulawiyat (prioritas hukum), yaitu yang wajib harus lebih didahulukan daripada yang sunnah. Artinya, kuliah harus lebih diprioritaskan daripada menikah. Jika tetap ingin menikah, maka hukumnya tetap sunnah, tidak wajib, namun dia dituntut untuk dapat menjalankan dua hukum tersebut (menunt ut ilmu dan menikah) dalam waktu bersamaan secara baik, tidak mengabaikan salah satunya, disertai dengan keharusan memenuhi kesiapan menikah seperti diuraikan di atas, yakni kesiapan ilmu, harta, dan fisik

2. Hukum Menikah Bagi Mahasiswa, Sedang Dia Tidak Dapat Menjaga Dirinya Sebagian mahasiswa mungkin tidak dapat menjaga dirinya, yaitu jika tidak segera menikah maka dia akan terjerumus kepada perbuatan maksiat, seperti zina. Maka jika benar-benar dia tidak dapat menghindarkan kemungkinan berbuat dosa kecuali dengan jalan menikah, maka hukum asal menikah yang sunnah telah menjadi wajib baginya, sesuai kaidah syariat

${ }^{25}$ By On 21 Juli 2016 In Panduan Mahasiswa, Tips \& trik Tagged menikah, menikah saat kuliah, nikah sambil kuliah Leave a comment 


\section{DAFTAR PUSTAKA}

'Uwaidah, Syaikh Kamil Muhammad. Fiqih Wanita. Jakarta: Pustaka al-kautsar, 1998. Abdillah, Masykuri. "Distorsi Sakralitas Perkawinan Pada Masa Kini", dalam Mimbar Hukum No. 36 Tahun IX 1998.

Abdurrahman. Kompilasi Hukum Islam. Edisi I. Jakarta: Akademika Pressindo, 1992.

Al-Hamdani. Risalah Nikah Hukum Perkawinan Islam. Cet. 2. Jakarta: Pustaka Amani, 2002.

An Nuriy, Sayyid Abu Al Ma'aathiy. Kitab Baqi' Musnad Ahmad. 'Amman: Dar'Alamil Kutub, 1419.

At-tihami, Muhammad. Merawat Cintah Kasih Menurut Syriat Islam. Surabaya: Ampel Mulia, 2004.

Baihaqi, Ahmad Rafi. Membangun Syurga Rumah Tangga. urabayah: Gita Mediah Press, 2006.

Departemen Agama RI. Al-Qur'an dan Terjemahnya. Bandung: Gema Risalah Press, 1989.

Rofiq, Ahmad. Hukum Islam di Indonesia. Jakarta: PT. Raja Grafindo Persada, 1995.

Rusyd, Ibnu. Bidayatul Mujtahid wa Nihayatul Muqtasid. Cet. 2. Terj. Imam Ghazali Sa’id dan Ahmad Zaidun. Jakarta: Pustaka Amani, 2002.

Shomad, Abd. Hukum Islam (Penormaan Prinsip Syariah dalam Hukum Indonesia). Jakarta: Penerbit Kencana, 2010.

UU RI No. 1 Th. 1974 Tentang Perkawinan dan Kompilasi Hukum Islam. Cet. I; Yogyakarta: Pustaka Yustisia, 2008.

Walgito, B. Bimbingan Konseling Dan Perkawinan. Yogyakarta: Andi Yogyakarta, 2000 